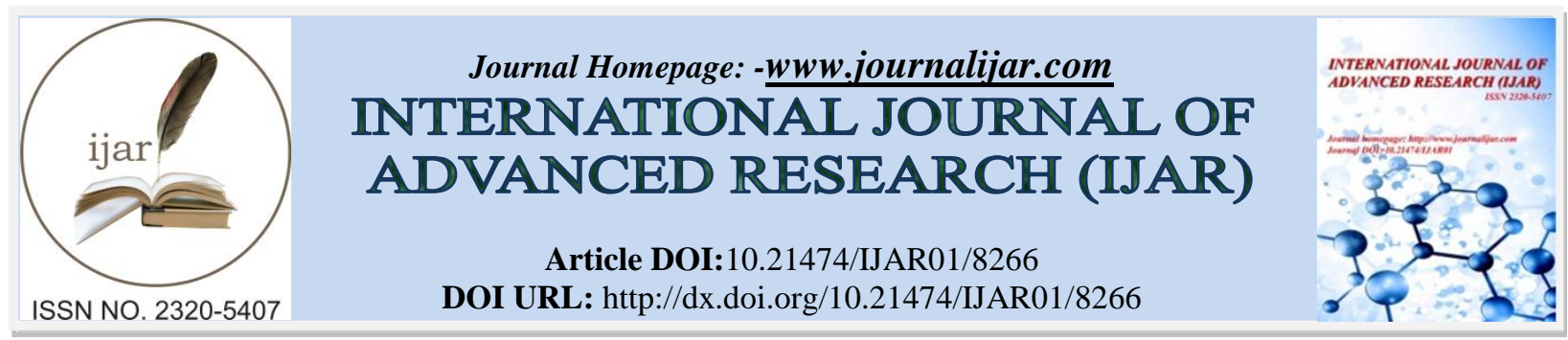

RESEARCH ARTICLE

\title{
THE IMPLEMENTATION OF GROUP INVESTIGATION, PROBLEM BASED LEARNING AND CRITICAL THINKING IN GEOMETRY LEARNING.
}

Edy Waluyo.

Hamzanwadi University.

\section{Manuscript Info}

\section{Manuscript History}

Received: 20 October 2018

Final Accepted: 22 November 2018

Published: December 2018

Keywords:-

Group Investigation, Problem Based

Learning, Critical Thinking.

\section{Abstract}

This study aimsto determinethe effectiveness of learning strategy and studensts' critical thinking ability in students' achievement of geometrystudent of Mathematics Study Program of Hamzanwadi University. The approach employed in this research wasquasi experiment with treatment by level design of $2 \times 2$. The targeted participant was students of mathematics study program of Hamzanwadi Universityin Academic Year which consists of three classes. Randomly selected two classes by each 32 participants were given to Learning Group Investigatian and Problem Based Learning.

The data gained from this study are critical thinking and students' achievement in Geometry. These data were analysed by Anova. The research depicted that (1) there was no difference learning achievement withlearning group investigation and problem based-learning, (2) there was significant effectiveness between learning strategies and critical thinking abilityin students' learning achievement of Geometry, (3) studentshaving high critical thinking ability obtained better learning achievement usinglearning group investigation compared to the problem based-learning (4) there was better learning achievement usingLearning Group Investigatian compared to the Problem BasedLearning for those students having low critical thinking ability.

Copy Right, IJAR, 2018,. All rights reserved.

\section{Introduction:-}

Some of learning strategies have been implemented in universities to achieve the level of success in the educational process. However, given the variation of objectives to be achieved, the different learning environment, students of different circumstances, different material characteristics, and others, then it can not formulate a good strategy for all types of learning activities. In the learning process, teachers should have a strategy to allow students to work effectively and efficiently, precisely on the expected goal. One step to have a strategy that is to be mastered the techniques of presentation of the material, or it is called learningstrategy.Every learning strategy can not be applied in any material, so that the selection of learning strategies is crucial in order to achieve the learning objectives. Therefore, before implementing learning activities, it is required careful thought in the selection of appropriate learning strategy for basic competencies to be served.Bloom cited by Reigeluth categorizes learning outcomes in three domains: (1) cognitive, (2) affective, and (3) psychomotor (1983: 52). Those should be targeted in every assessment of learning outcomes. Learning is an effort to teach students. To get adequate learning outcomes required the ability to think and reason as well as the existence of 
learning quality. Learningcontained meanings in an activity to own and develop a method, strategy, technique or approach to achieve the expected learning outcomes. According Reigeluth, there are three components of learning, namely: (1) conditions, (2) methods, and (3) outcomes (1983: 52).Learning group investigation begins by presenting the problem that provoked the attention of students. This is in accordance with the opinion of Joyce who said "the strategy begins by confronting the student with a stimulating problem" (2009: 281). Shlomo Sharon suggested six steps, namely the learning group investigation (1). Class determines subtopics of the problem and organizes into research groups, (2) groups plan their investigation, (3) groups carry out their investigations, (4) groups plan their presentation, (5) groups present their finding, (6) teacher and student evaluate the project(2013: 356 ). Robyn M. Gilles suggested six steps in the learning group investigation, among others: (1) Class determines sub topic and organizes into research groups, (2) group plan their investigation, (3) group carry out their investigation, (4) group plan their presentation/feedback, (5) group make their presentation, (6) teacher and student evaluate their project (2008 : 41). In the investigation group, student work freely, individually or in groups. Lecturer only acts as a motivator and facilitator who provided the impetus for students to be able to express their opinions or pour their thoughts and use their prior knowledge to understand the new situation. Lecturers also play a role in encouraging students to be able to improve their own results and the group's work.

Problem-based learning strategy begins with a presentation to the students a real problem. Departing from this problem expected, students easily acquire the concepts of the results of the investigation and inquiry. Cyndy E. Hmelo Silver and Cristina DeSimone argued that the "Problem Based Learning (PBL) is a learner centered pedagogical approach in which student engage in goal directed inquiry". (2013: 370).Linda Torp defined as a problem-based learning "Problem-based learning is focused, experimental learning (mind-on, hands-on) organized around the investigation and resolution of messy, real-world problems" (2002: 15). On the other hand, Oon Seng Tan believes "in PBL approaches, understanding is derived from the interaction with the problem scenario and the learning environment" (2004: 8). This means that, using problem-based learning share a kind of intelligence needed to solve real-world problems, the ability to deal with everything new and existing complexity. Barbara J. Duch expressed the problem-based learning process include: (1) Student are presented with a problem, (2) Throughourt discussion, student pose questions called learning issues that delineate aspects of the problem that they do not understand, (3) student rank, in order of importance, the learning issues generated in the session, (4) when student reconvence, they explore the previous learning issues, integrating their new knowledge into the context of the problem (2001: 7). In Mathematics Learning Strategies, confirmed that the problem-based learning is done through a phase of the phase as follows: (1) The orientation of the students on the issue; (2) organize the students to learn; (3) to guide investigations of individuals or groups; (4) develop and present work; (5) analyze and evaluate the problem solving process (2004: 11).

Critical thinking is a disciplined process intellectually where someone is actively and skillfully understand, apply, analyze, synthesize, or evaluate the information collected or drawn from experience, from observation, reflection is done, of reasoning or of the communications made (Chaldeans, 2012: 5). Richard L. Epstein defines critical thinking skills as "critical thinking is evaluating wheather we should be convincend that some claim is true or some argument is good, as well as formulating good argument" (2006: 5). David A. Hunter defines critical thinking as " critical thinking is thinking that is aimed at deciding what the believe or what to do (2009: 3 ). Based on the definition above definition, critical thinking ability is the students' ability to develop the ability to think, solve problems, and intellectual skills as well as being an independent learner. The purpose of this study are to determine (1) The difference in learning outcomes geometry lecture between students that are taught by using learning group investigation and problem-based learning, (2) The effect of the interaction between learning strategies and critical thinking ability to the learning outcomes of the geometry lecture, (3) the difference in learning outcomes of the geometry lecturethat is taught using learning group investigation and problem-based learning, for students who have high critical thinking ability, (4) the difference in learning outcomes of the geometry lecture that is taughtusing learning strategy investigation and problem-based learning, for students who have low critical thingking ability.

\section{Method:-}

The method used in this study was a quasi-experimental method. This study was made up of the main independent variable that is Learning Group Investigation and Problem Based Learning. Consisting of one variable attribute is the critical thingking ability, and one dependent variable is the result of learning geometry s. Students' critical thinking abilityof this study was divided into high critical thinking ability and low critical 
thingking ability. Research design used in this research the treatment design by level 2 x 2 .The data analysis used of this research was descriptive analysis and differential analysis. Descriptive analysis presented includes the average, standard deviation and variance. Before testing hypothesis, differential was used to know the normality and homogeneity test data. Normality test was done by using test samples Lilliefors for all groups with a significance level of $5 \%$. It can be seen from the criteria if $\mathrm{L}_{\text {count }}>\mathrm{L}_{\text {table }}, \mathrm{H}_{0}$ is rejected and if $\mathrm{L}_{\text {count }}<\mathrm{L}_{\text {table }}, \mathrm{H}_{0}$ is accepted. Homogeneity test was done by using Bartlett test with the testing criteria, $\mathrm{H}_{0}$ is accepted if count <table at a significance level of 5\% (Kadir, 2010: 107). In testing the hypothesis of this study, the researcher used analysis of variance (ANOVA) by the treatment design by level 2 × 2 and continued using Dunnet's t-test (Gall, 2007: 318).

\section{Results And Discussions:-}

In accordance with the design of this research was the treatment design by level $2 \times 2$, further hypotheses that have been formulated in this researchused two-way Anova.The results of the ANOVA calculation are presented as in the table below.

Tabel 2:- The Results of Anova Two Way for the Students' Achievement of Geometry

\begin{tabular}{|c|c|c|c|c|c|}
\hline Variances & JK & $\begin{array}{l}\text { d } \\
\text { b }\end{array}$ & $\begin{array}{c}\mathbf{R J} \\
\mathbf{K}\end{array}$ & $\begin{array}{c}\mathbf{F}_{\mathrm{c}} \\
\text { ou } \\
\mathrm{nt}\end{array}$ & $\begin{array}{c}\mathbf{F}_{\text {ta }} \\
\text { ble } \\
\alpha= \\
\mathbf{0 . 0} \\
5\end{array}$ \\
\hline $\begin{array}{c}\text { Between } \\
\text { A }\end{array}$ & 0.36 & 1 & 0.36 & $\begin{array}{c}0 . \\
0 \\
0 \\
8 \\
\end{array}$ & $\begin{array}{l}4.0 \\
8\end{array}$ \\
\hline $\begin{array}{c}\text { Between } \\
\text { B }\end{array}$ & $\begin{array}{l}301 \\
1.27\end{array}$ & 1 & $\begin{array}{l}301 \\
1.27\end{array}$ & $\begin{array}{l}6 \\
5 . \\
8 \\
2\end{array}$ & $\begin{array}{c}4.0 \\
8\end{array}$ \\
\hline $\begin{array}{c}\text { Interaction } \\
\mathrm{AxB}\end{array}$ & $\begin{array}{c}268 . \\
09\end{array}$ & 1 & $\begin{array}{c}268 . \\
09\end{array}$ & $\begin{array}{l}5 . \\
8 \\
6\end{array}$ & $\begin{array}{c}4.0 \\
8\end{array}$ \\
\hline In & $\begin{array}{l}176 \\
3.82 \\
\end{array}$ & $\begin{array}{l}4 \\
0 \\
\end{array}$ & $\begin{array}{c}45.7 \\
5 \\
\end{array}$ & & \\
\hline Total & $\begin{array}{l}510 \\
6.55 \\
\end{array}$ & $\begin{array}{l}4 \\
3 \\
\end{array}$ & & & \\
\hline
\end{tabular}

Based on the analysis in the table 2 above, it can be concluded that as follows:

The difference results between students taughtusing learning group investigation and problem-based learning:-

Based on the results of two way ANOVA obtained $F_{\text {count }}=0.008$ and $F_{t}(0.05 ; 1 / 40)=4.08$. Since $F_{\text {count }}<F_{\text {table }}$ then $\mathrm{H}_{0}$ was accepted. It can be concluded that the students'achievement of the students were taught geometry $\mathrm{s}$ using learning group investigation is not the same compared with the results of students' achievementwere taught geometryusing problem-based learning. This means that both thelearning group investigation and problem-based learning does not affect the geometry of learning achievement.

The interaction between learning strategies and critical thinking ability to the students' achievement of Geometry:-

Based on the result of ANOVA two way obtained $F_{\text {count }}=5.86(0.05 ; 1 / 40)=4.08$. Because the $F_{\text {count }}>F_{\text {table }}$ then $\mathrm{H}_{0}$ was rejected. It can be concluded that there were significant interaction between learning strategies and critical thinking ability to the students' achievement of geometry. In graphic form, the interaction between learning strategies and critical thinking ability to thestudents' achievement of the geometry can be seen in the figure below.

Based on the second hypothesis testing that there was interaction between learning strategies and critical thinking ability to the students' achievement of geometryso there should be further tested by using t-Dunnet. 
Table 3:-The results of t-Dunnet

\begin{tabular}{|c|c|c|c|c|}
\hline Groups & $\begin{array}{c}\mathbf{t}_{\text {cou }} \\
\text { nt }\end{array}$ & $\mathbf{t}_{\text {table }}$ & $\mathbf{H}_{1}$ & Conclusion \\
\hline $\begin{array}{l}\mathrm{A}_{1} \mathrm{~B}_{1}- \\
\mathrm{A}_{2} \mathrm{~B}_{1}\end{array}$ & $\begin{array}{r}1.7 \\
7 \\
\end{array}$ & $\begin{array}{c}1.68 \\
4 \\
\end{array}$ & $\begin{array}{l}\mathrm{A}_{1} \mathrm{~B}_{1}>\mathrm{A}_{2} \\
\mathrm{~B}_{1}\end{array}$ & $\begin{array}{l}\mathrm{H}_{\mathrm{o}} \text { was } \\
\text { rejected }\end{array}$ \\
\hline $\begin{array}{l}\mathrm{A}_{1} \mathrm{~B}_{2}- \\
\mathrm{A}_{2} \mathrm{~B}_{2}\end{array}$ & $\begin{array}{r}- \\
1.6 \\
4\end{array}$ & $\begin{array}{c}- \\
1.68 \\
4\end{array}$ & $\begin{array}{l}\mathrm{A}_{1} \mathrm{~B}_{2}<\mathrm{A}_{2} \\
\mathrm{~B}_{2}\end{array}$ & $\begin{array}{l}\mathrm{H}_{\mathrm{o}} \text { was } \\
\text { accepted }\end{array}$ \\
\hline
\end{tabular}

Based on the results of further tests in the above table can be deduced as follows:

The difference between the results ofstudents taught using learning group investigations than students taught usingproblems based learning to the students having highcritical thingking:-

Based on the results of a further test of the on the Table 3 , the obtained $t=1.77$ were higher than $t(0.05 ; 11)=$ 1.684. Because $t=1.77>\mathrm{t}$ table $=1.68$ then $\mathrm{H}_{0}$ was rejected. It can be concluded that for students having high critical thinking ability, students' achievement of geometry taught using learning group investigation was higher than the students taught using problems based learning. This can be seen in Table 3 , for students who have high critical thingking ability, the mean scores of the students' achievement of geometriusinglearning group investigation was 72.00 and the students taught using problem-based learning was 66.91. So, for those students who have high critical thinking ability, students' achievement of geometry taught using learning group investigation was higher than the students' achievement of geometryusing problem-based learning.

The difference results between students' achievement of geometry taught using learning group investigation and students taught using problem based learning for the students having low critical thingking ability:-

Based on the results as shown in Table 3 , therewas $t=-1.64$ higher than $t(0.05 ; 11)=-1.684$. Because tcount $>$ ttable then Howas accepted. It can be concluded that for students having low critical thingking ability, the students' achievement of geometry taught using learning group investigation was not lower than the students' achievement of geometry taught using the problem based learning. Meanwhile, for students having low critical thingking ability, the mean score for the students' achievement of geometry taught using learning group investigation was 50.55 and the students taught using problem-based learning was $55.27\left(\bar{X}_{A_{1} B_{2}}=50.55<\right.$ $\left.\bar{X}_{A_{2} B_{2}}=55.27\right)$. Although, for those students having low critical thingking ability, the students' achievement of geometry taught using learning group investigation waslower than the students' achievement of geometry taught using problem based learning. Statistics shoewd that there was no significantly different. Therefore, wheather learning group investigation and problem-based learning did not affect the students' achievement of geometry for the students having low critical thingking ability.

\section{Discussion:-}

In the first hypothesis testing shows that there was no significantly differentfor the students' achievement of geometry taught using learning group investigation was lower than the students' achievement of geometry taught using problem based learning. Theoretically, as described in chapter II basically learning group investigation and Problem Based Learning are the same. Learning group Investigation and problem-based learning are both student-centered learning. A difference of learning group investigation and problem based learning is a determination of the issues to be studied. In the learning group investigation, the problem is determined by the student, while on Problem Based Learning student must provide solutions to problems related to that given by the lecturer. This is consistented with the theory put forward by Nurhadi as quoted by Made Wena stated that the Learning Group Investigation requires the involvement of students from good planning in determining the topic as well as a way to learn through investigation (2014: 195). Therefore the learning group investigation students are given responsibility in their work, either individually, in pairs and in groups. Meanwhile, According to Tan was quoted as saying by Rusman mention that problem-based learning is an innovation of learning because the learning process students' thinking ability too well optimized through group work or team that systematically so that students can empower, sharpening, test and develop the capacity to think sustainably (2012: 229). Through the stages of problem-based learning strategies, students will gain experience in analyzing the problems presented through group discussions, to find solutions to these problems. Based on the above, it can be argued that none of the most superior learning strategies compared to other learning strategies. 
There is no learning strategy that fits all material. Each of the selected learning strategies teacher or lecturer in learning has advantages and disadvantages of each. Therefore, teachers or lecturers in teaching must be able to choose the right strategy in accordance with the characteristics of the material to be covered.

The second hypothesis testing showed that there was significantly interaction between learning strategies and critical thinking ability to the students' achievement of geometry. One of the life skills that should be developed through a process of education is students' critical thinking ability. Thinking ability largely determines one's ability to be able to achieve success in life. If the thinking ability of a person is very low then the success will be difficult to achieve, and if thinking ability possessed high enough then success will be easily achieved. Critical thinking ability can be developed through a variety of activities such as to improve theiranalysis, develop observable, increases curiosity, and discussion. Lecturers need to help students to develop critical thingking ability through strategies and methods that support students actively to learn. Learning is an active process of constructing meaning of learners in the form of text, dialogue, physical experience, and others. Learning is also a process of assimilating and connecting experience or materials are studied with the understanding that already belongs to someone so understanding developed. In developing the students' thinking requires the ability to think critically so that it can easily discover new knowledge. Learning strategies and critical thingking are factors that influence student results. If the learning strategies of problem-based learning and learning group investigation are not supported by the students' critical thinking ability then the result is less than optimal. Otherwise, if the student has high ability to think, but the lecturer does not facilitate learning strategy that supports the result is less than optimal. Both must be integrated.

The third hypothesis testing showed that for students who have high critical thinking ability, the students' achievement of geometry taught using learning group investigationwas higher than the the students' achievement of geometry taught using problem based learning. Learning is an active process of constructing meaning learners in the form of text, dialogue, physical experience, and others. Learning is also a process of assimilating and connecting experience or materials are studied with the understanding that already belongs to someone so understanding developed. In developing the thinking of students requiring critical thinking ability so that they can easily find the new knowledge. So, the student results in an optimal learning can take the necessary critical thinking abilityis high and students are required always active in learning. Students' critical thinking ability need to be developed through a process of education. Critical thinking ability will determine the person's ability to be able to achieve success in life. This implies, if the thinking ability possessed high enough then success will be easy to achieve in his life. Critical thinking ability can also specify the person's ability to overcome the existing problems in his life. Lecturers need to help students to develop thinking skills in learning. Thus, students who have high critical thinking ability have better thanstudents who have low critical thinking ability for the students' achievement of geometry .

The fourth hypothesis testing, Howas accepted. This suggests that for students who have low critical thingking ability, the students' achievement of geometry taught using learning group investigation was higher than the students' achievement of geometry taught using problem based learning. As in the first hypothesis, researchers said there were some things that Ho did not successfully rejected among other instruments and the sample study. As already described in chapter II that learning Group Investigation and Problem Based learning is an innovative learning-centered college student and has not been widely implemented by lecturers, especially mathematics lecturers of STKIP Hamzanwadi Selong so it is possible readiness of lecturers in implementing the learning is not maximized although previously trained and cause the indicator to be achieved have not completed the implementation of learning. In addition, the sample of the study also possible caused unsuccessful Ho rejected in this research so we need a larger sample size in the study. However, according to the researchers' critical thinking ability will determine the person's ability to be able to achieve success in learning. This implies, if the critical thinking ability possessed by students is very low then the success will be difficult to achieve. Learning strategies and critical thinking ability are the factors that influence student results. If the learning Group Investigation and Problem Based Learning is not supported by the students' critical thinking ability then the result is less optimal. Otherwise, if the student has high ability to think, but the lecturer does not facilitate learning strategy that supports the resultless optimal.

\section{Conclusion and recommendation:-}

Based on the results of research and discussion can be concluded as follows: (1) There was no difference in the students' achievement of geometry taught using learning group investigation was higher than the students' 
achievement of geometry taught using problem based learning, (2) There was an interaction between learning strategies and critical thinking ability for the students' achievement of geometry, (3) for the student who has high critical thingking ability, the students' achievement of geometry taught using learning group investigation was higher than the students' achievement of geometry taught using problem-based learning, (4) for the student who has low critical thingking ability, the students' achievement of geometry taught using learning group investigation was lower than the students' achievement of geometry taught using problem-based learning. Based on the above conclusions, the recommendations of the research results are:

First, based on the results of the study that there was no difference in the students' achievement of geometry taught using learning group investigation was higher than the students' achievement of geometry taught using problem based learning. Based on the data, the mean score of the students taught using learning group investigation was 61.27 while the students' achievement of geometry taught using problem-based learning was 61.09. These data show that, statistically, the results of the students' achievement of geometry taught using learning group investigation was no difference or the same as the result of the students' achievement of geometry taught using problem based learning. This suggests that, none of learning strategies appropriate or suitable to be applied to all areas of study and students. This means that learning strategies will be applied lecturer or teacher in the learning must be adapted to existing conditions.

Second, the results showed that there is an interaction between learning strategies and critical thinking abilityfor the students' achievement of geometry. This means that the students' achievement acquired during learning is influenced by the appropriate learning strategies and critical thinking ability. Teacher or lecturer in implementing the learning should be able to choose learning strategies in accordance with the critical thinking ability of the students. Teachers and lecturers should be able to use learning strategies in accordance with the exciting and innovative students' characteristics and the characteristics of the field of study so that students' critical thinking ability or a student may be developed during the learning process.

Third, the results showed that for students who have high critical thinking ability, the students' achievement of geometry was higher using learning group investigation compared with the students' achievement of geometry was higher using problem-based learning. This means that the learning group investigation was suitable for students having high critical thinking ability. To improve students' achievement of geometry, the lecturers need to adjust the selected learning strategies with students' critical thinking ability.

Fourth, the results showed that for students who have low critical thinking ability, the students' achievement of geometry taught usingLearning Group Investigation was not lower than the students' achievement of geometry taught using problem based learning even. It is seen from the mean score of the students' achievement of geometry taught using learning Group Investigation was lower than the students' achievement of geometry taught using problem Based learning. Therefore, in selecting the learning strategies that will be used to pay attention to the students' critical thingkingability.

\section{References :-}

1. Charles M. (1983). Instructional Design theories and strategis, London: Lawrence Erlbaum Associates, Inc,

2. Cindy E. Hmelo Silver, Clark A. Chinn. (2013).The International Handbook of Collaborative Learning, New York: Routledge.

3. D.Gall, Meredith et al. (2007).Educational Research . Boston: Pearson Education.Departemen Agama. (2004).Strategi pembelajaran Matematika, Jakarta.

4. Duch, Barbara J. (2001).The Power of Problem Based Learning. Virginia: Stylus Publishing.

5. Epstein, Richard L. (2006).Critical Thinking, Canada: Thomson Wadsworth.

6. Gagne,Robert M. (2005). Principles of Instructional Design.Belmont: wadsworth, a division of Thomson Learning, Inc.

7. Gilles, Robyn M. (2008). The Teacher's Role in Implementary Cooperative Learning in the Classroom, New York: Springer Science.

8. Hunter, David A. (2009). A Practical Guide to Critical Thinking. Canada: John Wiley \&Sons.

9. Joyce, Bruce.(2009). Strategis of Teaching.Boston: Pearson Education, Inc.

10. Kadir. (2010).Statistika. Jakarta: Rosemata Sampurna.

11. Linda Torp and Sara Sage. (2002). Problem as Possibilities Problem Based learning for K-16 Education. Beauregard St: Assosiation for Supervision and curriculum Development. 
12. Made Wena. (2014).Strategi Pembelajaran Inovatif Kontemporer. Jakarta : PT Bumi Aksara.

13. Oon Seng Tan. (2004).Enchanging Thinking through Problem Base Learning Approaches.Singapore: a division of.

14. Rusman.(2012)Strategi Strategi Pembelajaran.Jakarta; PT Raja grafindo Persada.Sharon, Shlomo.(2014). Cooperative Learning.Jogjakarta: Istana Media.

15. Sihotang, Kasdin. (2012).Critical Thinking,Membangun Pemikiran Logis. Jakarta: Pustaka Sinar Harapan. 